\title{
METODE FUZZY SUGENO UNTUK PENILAIAN KINERJA GURU SMK TAMANSISWA 3 JAKARTA
}

\author{
Fanisya Alva Mustika \\ Program Studi Teknik Informatika, Universitas Indraprasta PGRI \\ funny.alva@gmail.com
}

Submitted February 10, 2021; Revised July 31, 2021; Accepted August 1, 2021

\begin{abstract}
Abstrak
Menentukan guru teladan atau guru berprestasi merupakan salah satu upaya dalam meningkatkan kinerja guru. Permasalahan yang terjadi pada SMK Tamansiswa 3 Jakarta adalah belum ada format yang baku mengenai penilaian kinerja guru. Oleh karena itu diperlukan sistem penilaian kinerja guru yang dapat membantu manajemen dalam menentukan guru dengan kinerja terbaik serta membantu manajemen dalam memberikan saran membangun untuk guru berdasarkan nilai yang diperoleh. Sistem ini dibuat dengan menggunakan logika fuzzy sugeno. Kriteria yang diterapkan dalam sistem ini antara lain : kesiapan materi, penggunaan media pembelajaran, objektif, pengembangan kurikulum, penguasaan materi, kehadiran, pengendalian kelas, kemampuan memotivasi siswa, kemampuan menciptakan suasana kelas yang menyenangkan. Kriteria dibagi dalam himpunan fuzzy baik, cukup, dan buruk. Hasil dari penelitian ini adalah sistem penilaian kinerja guru menggunakan metode fuzzy sugeno dengan tingkat akurasi sebesar 98,92\%.
\end{abstract}

Kata Kunci : Logika fuzzy, Sugeno, Guru, Sistem Pendukung Keputusan.

\begin{abstract}
Determine model teacher or teachers who performed well is one effort in improving on teacher performance.The problem in smk tamansiswa 3 jakarta is no fixed on the performance assessment teachers. Thus there needs the assessment system on teacher performance that can help in determining teachers with management best performance helped build management for providing advice for teachers based on the total score earned by. This system made by using fuzzy logic sugeno.Criteria that are applied in this system readiness matter, among others: learning, media uses, objective, curriculum development, their mastery of the material, the presence of, class control, ability motivate students, ability create a class pleasing. Criteria divided into the fuzzy good, enough and bad.The result of this research was the assessment system uses the teacher performance with the accuracy of fuzzy sugeno $98,92 \%$.
\end{abstract}

Key Words : Fuzzy Logic, Sugeno, Teacher, Decision Support System.

\section{PENDAHULUAN}

Pentingnya pendidikan ditegaskan pada Pembukaan UUD 1945 yang menyatakan bahwa salah satu tujuan negara adalah mencerdaskan kehidupan bangsa. Upaya mencerdaskan kehidupan bangsa ini memerlukan proses pendidikan. Salah satu hal penting dalam menyelenggarakan proses pendidikan tersebut adalah peran guru [1]. Dalam Undang-Undang Guru dan Dosen Nomor 14 Tahun 2005, guru adalah pendidik professional dengan tugas utama mendidik, mengajar, membimbing, mengarahkan, melatih, menilai dan mengevalusi peserta didik pada pendidikan anak usia dini jalur pendidikan formal, pendidikan dasar dan menengah [2]. Guru merupakan profesi atau jabatan yang memerlukan keahlian khusus, dimana pekerjaannya tidak bisa dilakukan oleh sembarang orang yang tidak memiliki keahlian sebagai guru [3].

Salah satu aspek menarik untuk dikaji dari guru adalah kinerja, karena kinerja guru 
merupakan input yang penting dalam penyelenggaraan pendidikan [4]. Untuk mengetahui tingkat kinerja guru, perlu dilakukan penilaian pada kemampuan guru dalam melaksanakan proses pendidikan dan pengajaran. Penilaian dilakukan dengan mengukur kinerja setiap guru dalam melaksanakan tugas dan kewajiban sesuai dengan standar kompetensi yang ada. [5]

Permasalahan yang terjadi pada SMK Tamansiswa 3 adalah belum adanya format baku mengenai penilaian kinerja guru. Berdasarkan permasalahan tersebut, perlu sebuah sistem pendukung keputusan penilaian kinerja guru yang dapat membantu manajemen dalam melakukan penilaian kinerja sehingga bisa menentukan guru dengan kinerja terbaik, menentukan solusi dan saran membangun untuk guru berdasarkan nilai kinerja yang diperoleh. Sistem pendukung keputusan merupakan sistem yang menyediakan informasi, pemodelan, dan pemanipulasian data. Sistem tersebut digunakan untuk membantu dalam proses pengambilan keputusan semiterstruktur dan situasi tidak terstruktur, di mana sesorang tidak tahu secara pasti bagaimana keputusan seharusnya dibuat [6]. Definisi lain menyatakan bahwa sistem pendukung keputusan adalah sebuah sistem berbasis komputer yang terdiri atas berbagai komponen antara lain komponen bahasa (language), komponen pengetahuan (knowledge) dan pemrosesan masalah (problem processing) yang saling berinteraksi satu dengan yang lainnya. [7]

Sistem penilaian kinerja dibuat dengan menggunakan pendekatan fuzzy sugeno. Logika fuzzy memiliki nilai kekaburan atau kesamaran antara benar dan salah. Dalam teori logika fuzzy suatu nilai dapat bernilai benar dan juga salah secara bersamaan. Tetapi seberapa besar kesalahan dan kebenaran nilai tersebut tergantung kepada bobot keanggotaan yang dimilikinya [8]. Himpunan fuzzy memperluas jangkauan fungsi karakteristik sedemikian hingga fungsi tersebut akan mencakup bilangan real pada interval $[0,1]$. [9]. Model Fuzzy Sugeno diajukan oleh Takagi, Sugeno, dan Kang. Sistem inferensi fuzzy metode Sugeno memiliki karakteristik, yaitu konsekuen bukan merupakan himpunan fuzzy, namun merupakan suatu persamaan linear dengan variabel sesuai dengan variabel inputnya.[10]

\section{METODE PENELITIAN}

Penelitian ini dilakukan dengan menggunakan pendekatan fuzzy tipe sugeno. Untuk mendapatkan output pada logika fuzzy, diperlukan 4 tahapan:

1. Pembentukan himpunan fuzzy. Langkah pertama pada proses fuzzy adalah menentukan variabel fuzzy dan menentukan himpunan fuzzynya. Selanjutnya adalah menentukan derajat keanggotaan antara data masukan fuzzy dengan himpunan fuzzy yang telah didefinisikan untuk setiap variabel masukan sistem dari setiap aturan fuzzy. Variabel input maupun variabel output dibagi menjadi satu atau lebih himpunan fuzzy.

2. Aplikasi fungsi implikasi. Hasil implikasi fuzzy dari setiap aturan ini kemudian digabungkan untuk menghasilkan keluaran inferensi fuzzy.

3. Komposisi Aturan (rule). Tidak seperti penalaran monoton, apabila sistem terdiri dari beberapa aturan, maka inferensi diperoleh dari kumpulan dan korelasi antar aturan. Ada 3 metode yang digunakan dalam melakukan inferensi sistem fuzzy, yaitu: max, additive dan probabilistik OR.

4. Penegasan (defuzzy). Input dari proses defuzzifikasi adalah suatu himpunan fuzzy yang diperoleh 
dari komposisi aturan-aturan fuzzy, sedangkan output yang dihasilkan merupakan suatu bilangan pada domain himpunan fuzzy tersebut.

Alur penelitian dilakukan sebagai berikut :

1. Pengumpulan data

Kegiatan pendahuluan yang dilakukan adalah mengumpulkan data serta informasi yang diperlukan. Peneliti mengumpulkan materi kepustakaan sesuai tema penelitian, kemudain melakukan wawancara serta mengambil data kuesioner. Sampel pada penelitian ini adalah 21 guru. Hasil dari kegiatan ini adalah kriteria penilaian kinerja guru dan data kuesioner penilaian guru yang diisi oleh Kepala Sekolah.

2. Analisis Data

Data-data yang dikumpulkan sebelumnya kemudian diolah menggunakan metode Fuzzy.

Variabel masukan fuzzy yang merupakan aspek penilaian kinerja guru sebagai berikut :

a. Kesiapan memberi materi

b. Penggunaan media pembelajaran

c. Objektif

d. Memeriksa dan membahas soal latihan

e. Mengembangkan kurikulum

f. Menguasai materi

g. Mengaitkan materi dengan kehidupan sehari-hari

h. Hadir tepat waktu

i. Pengendalian kelas

j. Dapat memotivasi siswa

k. Menciptakan suasana kelas yang menyenangkan.

Himpunan Fuzzy

Masing-masing kriteria dibagi dalam himpunan fuzzy baik dengan domain [70-100], himpunan fuzzy cukup dengan domain [40-80] dan himpunan fuzzy buruk dengan domain [0-50].
3. Pengolahan Data

Data diolah menggunakan pendekatan Logika Fuzzy dengan bantuan toolbox Matlab.

4. Evaluasi

Evaluasi dilakukan untuk menguji output dari aplikasi yang dihasilkan.

\section{HASIL DAN PEMBAHASAN}

Data yang digunakan dalam penelitian ini yaitu data kriteria penilaian dan data 21 guru yang dinilai.

Langkah pertama adalah melakukan dekomposisi variabel model menjadi himpunan fuzzy. Variabel yang digunakan sebagai berikut :

Tabel 1. Dekomposisi Variabel Model Himpunan Fuzzy

\begin{tabular}{clc}
\hline Fungsi & \multicolumn{1}{c}{ Nama Variabel } & Range \\
\hline Input & Siap memberi materi & {$[0-100]$} \\
& $\begin{array}{l}\text { Menggunakan media } \\
\text { pembelajaran }\end{array}$ & {$[0-100]$} \\
& Objektif & {$[0-100]$} \\
& Memeriksa dan Membahas & {$[0-100]$} \\
& Soal Latihan & \\
& Mengembangkan kurikulum & {$[0-100]$} \\
& Menguasai materi & {$[0-100]$} \\
& Mengaitkan materi dengan & {$[0-100]$} \\
& kehidupan sehari-hari & {$[0-100]$} \\
& Hadir tepat waktu & {$[0-100]$} \\
& Dapat mengendalikan kelas & {$[0-100]$} \\
& Dapat memotivasi siswa & {$[0-100]$} \\
& Menciptakan suasana kelas & \\
\hline \multirow{2}{*}{ Output } & Skong menyenangkan & {$[0-100]$} \\
\hline
\end{tabular}

Langkah selanjutnya adalah menentukan himpunan fuzzy. Setiap kriteria atau variabel masukan dibentuk dalam himpunan fuzzy sebagai berikut : 
Tabel 2. Himpunan Fuzzy

\begin{tabular}{|c|c|c|}
\hline Variabel & $\begin{array}{l}\text { Himpunan } \\
\text { Fuzzy }\end{array}$ & Domain \\
\hline \multirow[t]{3}{*}{ Siap memberi materi } & Buruk & {$[0-50]$} \\
\hline & Cukup & {$[40-80]$} \\
\hline & Baik & {$[70-100]$} \\
\hline \multirow{3}{*}{$\begin{array}{l}\text { Menggunakan media } \\
\text { pembelajaran }\end{array}$} & Buruk & {$[0-50]$} \\
\hline & Cukup & {$[40-80]$} \\
\hline & Baik & {$[70-100]$} \\
\hline \multirow[t]{3}{*}{ Objektif } & Buruk & {$[0-50]$} \\
\hline & Cukup & {$[40-80]$} \\
\hline & Baik & {$[70-100]$} \\
\hline \multirow{3}{*}{$\begin{array}{l}\text { Memeriksa dan membahas } \\
\text { soal latihan }\end{array}$} & Buruk & {$[0-50]$} \\
\hline & Cukup & {$[40-80$ ] } \\
\hline & Baik & {$[70-100]$} \\
\hline \multirow[t]{3}{*}{$\begin{array}{l}\text { Mengembangkan } \\
\text { kurikulum }\end{array}$} & Buruk & {$[0-50]$} \\
\hline & Cukup & {$[40-80]$} \\
\hline & Baik & {$[70-100]$} \\
\hline \multirow[t]{3}{*}{ Menguasai materi } & Buruk & {$[0-50]$} \\
\hline & Cukup & {$[40-80]$} \\
\hline & Baik & {$[70-100]$} \\
\hline \multirow{3}{*}{$\begin{array}{l}\text { Mengaitkan materi dengan } \\
\text { kehidupan sehari- } \\
\text { Hari }\end{array}$} & Buruk & {$[0-50]$} \\
\hline & Cukup & {$[40-80]$} \\
\hline & Baik & {$[70-100]$} \\
\hline \multirow[t]{3}{*}{ Hadir tepat waktu } & Buruk & {$[0-50]$} \\
\hline & Cukup & {$[40-80]$} \\
\hline & Baik & {$[70-100]$} \\
\hline \multirow[t]{3}{*}{ Dapat mengendalikan kelas } & Buruk & {$[0-50]$} \\
\hline & Cukup & {$[40-80]$} \\
\hline & Baik & {$[70-100]$} \\
\hline \multirow[t]{3}{*}{ Dapat memotivasi siswa } & Buruk & {$[0-50]$} \\
\hline & Cukup & {$[40-80]$} \\
\hline & Baik & {$[70-100]$} \\
\hline $\begin{array}{l}\text { Menciptakan suasana kelas } \\
\text { yang }\end{array}$ & Buruk & {$[0-50]$} \\
\hline \multirow[t]{2}{*}{ Menyenangkan } & Cukup & {$[40-80]$} \\
\hline & Baik & {$[70-100]$} \\
\hline
\end{tabular}

Semesta pembicaraan setiap variabel adalah [0 - 100]. Variabel ini dibagi dalam tiga himpunan fuzzy, yaitu Buruk, Cukup, dan Baik. Himpunan fuzzy Buruk memiliki domain [0-50], himpunan fuzzy Cukup memiliki domain [40-80], dan himpunan fuzzy Baik memiliki domain [70-100].

Variabel tiap kriteria dipresentasikan dalam kurva linear dan segitiga sebagai berikut :

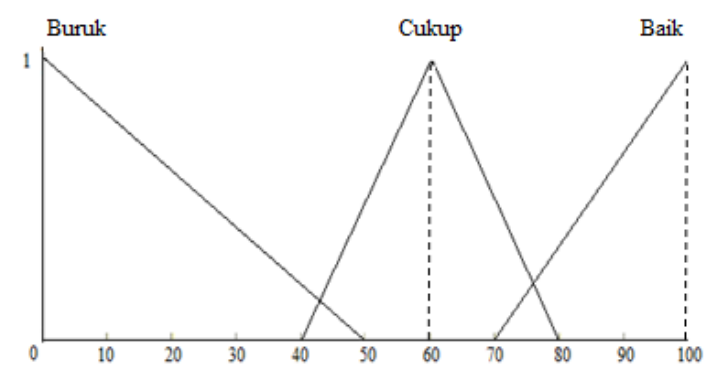

Gambar 1. Himpunan Fuzzy Variabel

Gambar diatas merupakan kurva linear dan segitiga untuk setiap kriteria yang dibagi dalam 3 himpunan fuzzy yaitu baik, cukup, dan buruk.

Persamaan :

$\mu$ Kurang $[x]$

$=\left\{\begin{array}{cl}(50-x) /(50-0) & ; 0 \leq x \leq 50 \\ 0 & ; x \geq 50\end{array}\right.$

$\mu \operatorname{Cukup}[x]$

$= \begin{cases}0 & ; x \leq 40 \text { atau } x \geq 80 \\ (x-40) /(60-40) & ; 40 \leq x \leq 60 \\ (80-x) /(80-60) & ; 60 \leq x \leq 80\end{cases}$

$$
\begin{aligned}
& \mu \text { Baik }[x] \\
& =\left\{\begin{array}{cl}
0 & ; x \leq 70 \\
(x-70) /(100-70) & ; 70 \leq x \leq 100 \\
1 & ; x \geq 100
\end{array}\right.
\end{aligned}
$$




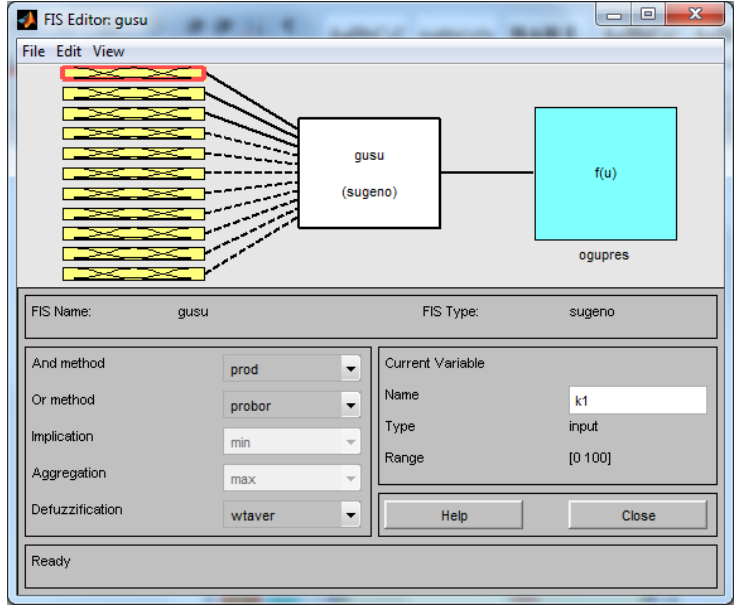

Gambar 2. FIS Editor Penilaian Guru

Gambar di atas adalah tampilan fuzzy inference sistem editor tipe sugeno untuk penilaian kinerja guru dengan 11 input atau kriteria.

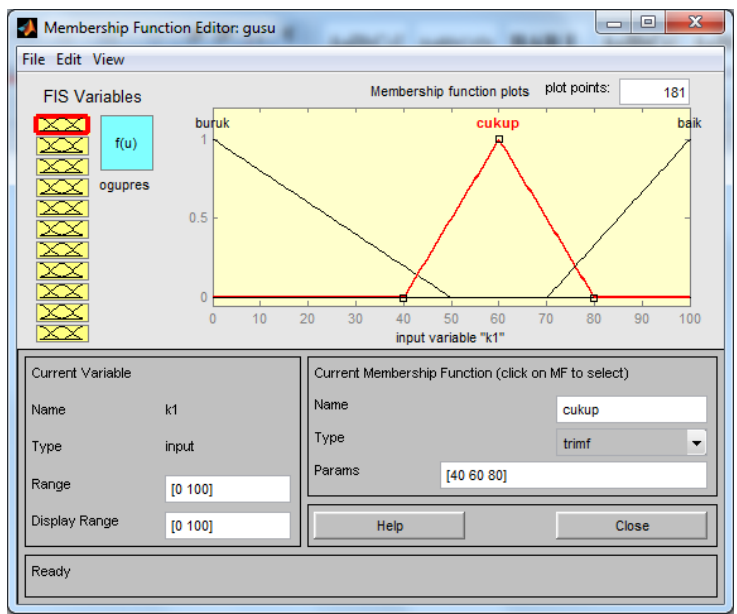

Gambar 3. Fungsi Kenggotaan Variabel Masukan

Gambar di atas adalah tampilan fungsi keanggotan salah satu variabel input fuzzy yaitu variabel siap memberi materi. Semesta pembicaraan dari variabel siap memberi materi adalah [0-100]. Variabel ini dibagi dalam tiga himpunan fuzzy, yaitu Buruk, Cukup, dan Baik. Himpunan fuzzy Buruk memiliki domain [0-50], himpunan fuzzy Cukup memiliki domain [40-80] , dan himpunan fuzzy Baik memiliki domain [70-100].

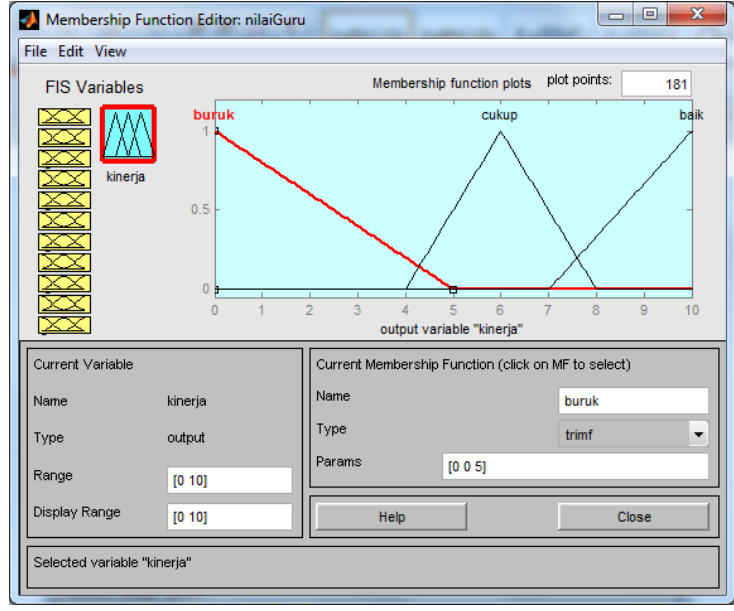

Gambar 4. Fungsi Keanggotaan Output Kinerja Guru

Gambar di atas adalah tampilan fungsi keanggotan salah variabel output fuzzy yaitu variabel kinerja. Semesta pembicaraan atau range dari variabel output kinerja adalah [0-10]. Variabel ini dibagi dalam tiga himpunan fuzzy, yaitu Buruk, Cukup, dan Baik. Himpunan fuzzy Buruk memiliki domain [0-5], himpunan fuzzy Cukup memiliki domain [4-8], dan himpunan fuzzy Baik memiliki domain [710].

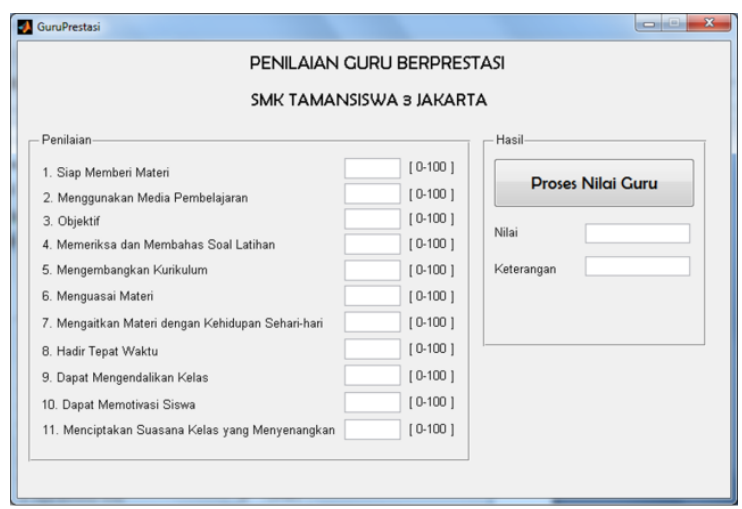

Gambar 5. Rancangan Tampilan Sistem

Gambar di atas merupakan tampilan sistem pendukung keputusan penilaian kinerja guru untuk SMK Tamansiswa 3 Jakarta dengan 11 kriteria penilaian. Range nilai untuk masing-masing kriteria adalah [0100]. Hasil yang ditampilkan setelah input nilai kriteria adalah nilai akhir dan keterangan kinerja guru berupa kinerja baik, cukup atau buruk. 


\section{Pembentukan Aturan Fuzzy}

Berdasarkan hasil kuesioner dan wawancara yang diajukan kepada Kepala Sekolah, maka didapatkan 20 kombinasi aturan fuzzy. Setiap aturan menyertakan semua variabel. Metode inferensi fuzzy yang digunakan adalah Metode Sugeno orde-satu. Pada Metode ini, antesenden dipresentasikan dengan proposisi dalam himpunan fuzzy, sedangkan konsekuen dipresentasikan dengan persamaan linear.

Salah satu aturan yang telah dibuat sebagai berikut :

IF $\mathrm{k} 1$ is Baik and $\mathrm{k} 2$ is Cukup and $\mathrm{k} 3$ is Baik and $\mathrm{k} 4$ is Baik and $\mathrm{k} 5$ is Baik and k6 is Baik and $\mathrm{k} 7$ is Baik and $\mathrm{k} 8$ is Baik and $\mathrm{k} 9$ is Baik and $\mathrm{k} 10$ is Baik and $\mathrm{k} 11$ is Cukup THEN osuge $=0.09 * \mathrm{k} 1+0.09 * \mathrm{k} 2$ $+0.09 * \mathrm{k} 3+0.09 * \mathrm{k} 4+0.09 * \mathrm{k} 5+0.09 * \mathrm{k} 6$ $+0.09 * \mathrm{k} 7+0.1 * \mathrm{k} 8+0.09 * \mathrm{k} 9+0.09 * \mathrm{k} 10$ $+0.09 * \mathrm{k} 11$

Dari aturan yang telah disusun berdasarkan keputusan kepala sekolah nantinya dapat digunakan sebagai penentuan keputusan dalam penilaian kinerja guru.

\section{Evaluasi}

Aplikasi dibuat menggunakan program Matlab. Untuk pengujian digunakan data hasil kuesioner guru SMK Tamansiswa 3 yang dibuat oleh Kepala Sekolah.

Setelah proses input data selesai, selanjutnya dilakukan proses penilaian kinerja guru yang menghasilkan output berupa nilai guru, hasil kinerja guru berupa kinerja baik, buruk atau cukup. Berikut adalah contoh input dan output pada sistem penilaian kinerja guru.

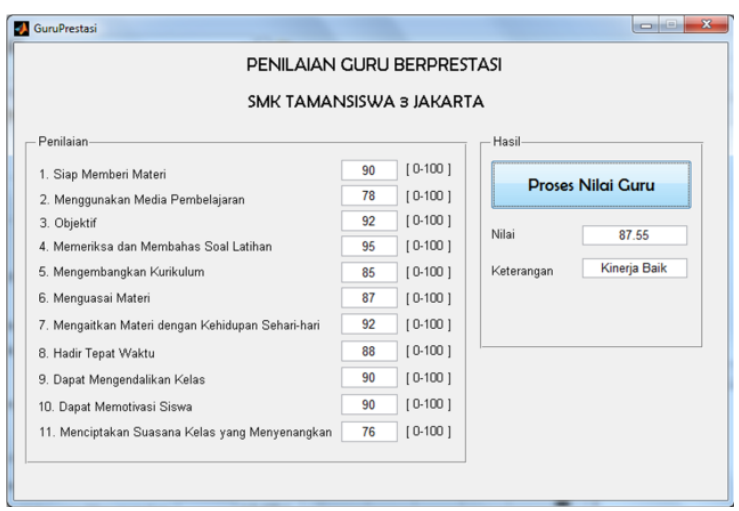

Gambar 6. Sistem Penilaian Kinerja Guru

Berdasarkan hasil uji coba menggunakan data hasil kuesioner maka diperoleh nilai akurasi sistem penilaian kinerja guru menggunakan logika fuzzy sebesar 98,92\%. Hasil pengujian terhadap beberapa kombinasi menunjukkan bahwa tingkat kesalahan perhitungan model yang dibuat adalah 1,08\%. Tingkat Kesalahan ini lebih kecil dari tingkat kesalahan pada penelitian sejenis dengan menggunakan metode mamdani.

\section{SIMPULAN}

Simpulan dari penelitian ini adalah sistem penilaian kinerja guru dapat dibangun dengan pendekatan logika fuzzy. Sistem penilaian kinerja guru menggunakan logika fuzzy dengan 11 kriteria penilaian yang dibuat memiliki tingkat akurasi sebesar 98,92\%. Sistem penilaian kinerja guru yang dibuat dapat membantu manajemen sekolah untuk mengetahui kinerja setiap guru, menentukan guru dengan kinerja terbaik dan membantu menentukan solusi dan saran untuk guru sesuai hasil nilai kinerja yang diperoleh.

\section{DAFTAR PUSTAKA}

[1] Warsono, "Guru: Antara Pendidik, Profesi, Dan Aktor Sosial," J. Soc. Media, vol. 1, no. 1, pp. 1-10, 2017.

[2] H. Darmadi, "Tugas, Peran, Kompetensi, dan Tanggung Jawab Menjadi Guru Profesional," Edukasi J. Pendidik., vol. 13, no. 2, pp. 161- 
174, 2015.

[3] Heriyansyah, "Guru Adalah Manajer Sesungguhnya Di

Sekolah," J. Manaj. Pendidik. Islam, vol. 1, no. 01, pp. 116-127, 2018.

[4] Koswara and Rasto, "Kompetensi Dan Kinerja Guru Berdasarkan Sertifikasi Profesi," J. Pendidik. Manaj. Perkantoran, vol. 1, no. 1, p. 61, 2016.

[5] W. A. Ariefiandi, G. Abdillah, and R. Ilyas, "Sistem Pendukung Keputusan Penilaian Kinerja Guru SMA Menggunakan Metode Analytical Hierarchy Procces ( AHP ) dan Weighted Product ( WP )," in Seminar Nasional Teknologi Informasi dan Multimedia, 2017, pp. 85-90.

[6] R. Ganevi and B. Eka Purnama, "Sistem Pendukung Keputusan Penilaian Kinerja Guru Sekolah Menengah Pertama Negeri (SMP N) 1 Pacitan," J. Speed-Sentra Penelit.
Eng. dan Edukasi, vol. 6, no. 4, pp. 38-43, 2014.

[7] I. N. Hanifah, "Sistem Pendukung Keputusan Pemilihan Guru Berprestasi Dengan Simple Additive Weighting," J. Tek. Elektro, vol. 6, no. 1, p. 45, 2014.

[8] M. Simanjuntak and A. Fauzi, "Penerapan Fuzzy Mamdani Pada Penilaian Kinerja Dosen (Studi Kasus STMIK Kaputama Binjai)," J. ISD, vol. 2, no. 2, pp. 143-149, 2017.

[9] D. P. P. Astuti and Mashuri, "UNNES Journal of Mathematics," UNNES J. Math., vol. 9, no. 2, pp. 125-130, 2020.

[10] S. L. M. Sitio, "Penerapan Fuzzy Inference System Sugeno untuk Menentukan Jumlah Pembelian Obat (Studi Kasus: Garuda Sentra Medika)," J. Inform. Univ.

Pamulang, vol. 3, no. 2, p. 104, 2018. 